\title{
Advances and complications of regenerative medicine in diabetes therapy
}

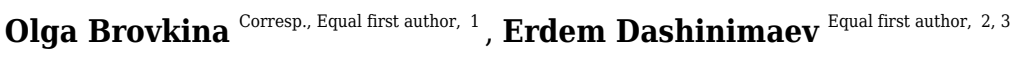 \\ ${ }^{1}$ Federal Research Clinical Center for Specialized Types of Health Care and Medical Technologies of Federal Medical and Biology Agency, Moscow, Russia \\ 2 Koltzov Institute of Developmental Biology of Russian Academy of Sciences, Moscow, Russia \\ 3 Pirogov Russian National Research Medical University, Moscow, Russia \\ Corresponding Author: Olga Brovkina \\ Email address: brov.olia@gmail.com
}

The rapid development of technologies in regenerative medicine indicates clearly that their common application is not a matter of if, but of when. However, the regeneration of beta-cells for diabetes patients remains a complex challenge due to the plurality of related problems. Indeed, the generation of beta-cells masses expressing marker genes is only a first step, with maintaining permanent insulin secretion, their protection from the immune system and avoiding pathological modifications in the genome being the necessary next developments. The prospects of regenerative medicine in diabetes therapy were promoted by the emergence of promising results with embryonic stem cells (ESCs). Their pluripotency and proliferation in an undifferentiated state during culture have ensured the success of ESCs in regenerative medicine. The discovery of induced pluripotent stem cells (iPSCs) derived from the patients' own mesenchymal cells has provided further hope for diabetes treatment. Nonetheless, the use of stem cells has significant limitations related to the pluripotent stage, such as the risk of development of teratomas. Thus, the direct conversion of mature cells into beta-cells could address this issue. Recent studies have shown the possibility of such transdifferentiation and have set trends for regeneration medicine, directed at minimizing genome modifications and invasive procedures. In this review, we will discuss the published results of beta-cell regeneration and the advantages and disadvantages illustrated by these experiments. 
1 Advances and complications of regenerative medicine 2 in diabetes therapy

3

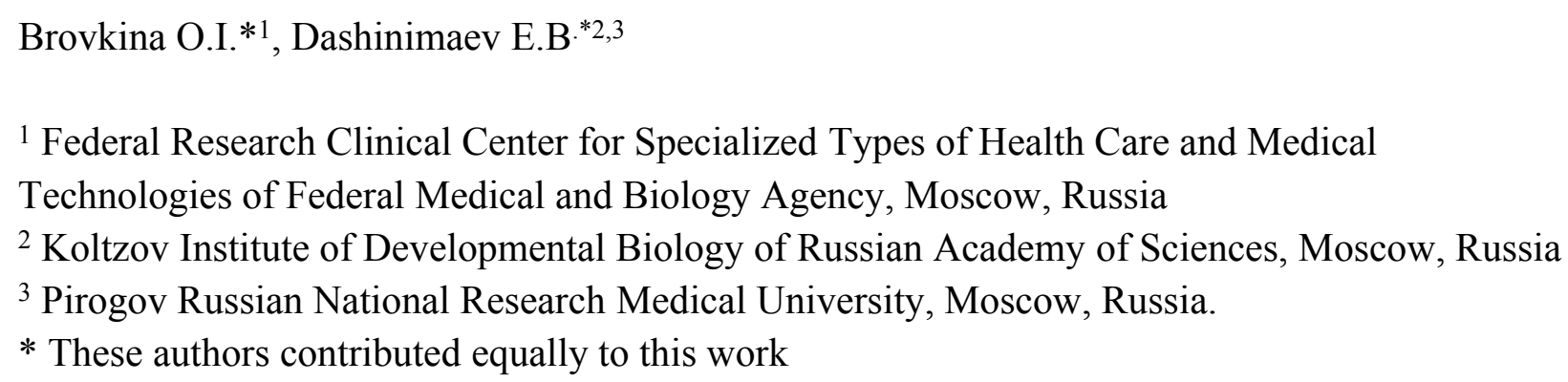

\section{Abstract}

The rapid development of technologies in regenerative medicine indicates clearly that their common application is not a matter of if, but of when. However, the regeneration of beta-cells for diabetes patients remains a complex challenge due to the plurality of related problems. Indeed, the generation of beta-cell mass expressing marker genes is only a first step, with maintaining permanent insulin secretion, their protection from the immune system and avoiding pathological modifications in the genome being the necessary next developments. The prospects of regenerative medicine in diabetes therapy were promoted by the emergence of promising results with embryonic stem cells (ESCs). Their pluripotency and proliferation in an undifferentiated state during culture have ensured the success of ESCs in regenerative medicine. The discovery of induced pluripotent stem cells (iPSCs) derived from the patients' own mesenchymal cells has provided further hope for diabetes treatment. Nonetheless, the use of stem cells has significant limitations related to the pluripotent stage, such as the risk of development of teratomas. Thus, the direct conversion of mature cells into beta-cells could address this issue. Recent studies have shown the possibility of such transdifferentiation and have set trends for regeneration medicine, directed at minimizing genome modifications and invasive procedures.

In this review, we will discuss the published results of beta-cell regeneration and the advantages and disadvantages illustrated by these experiments.

\section{Introduction}

Diabetes mellitus is a widespread and socially significant disease that leads to a deterioration in the quality of life and life expectancy of patients. Patients with type I diabetes (T1D) are 
40 characterized by a deficiency of the pancreatic beta-cells mass, which can represent a loss of 41 between 70-100\% (Lam \& Cherney, 2018). Traditionally, T1D can be separated from type II 42 diabetes (T2D) by the factors triggering it, age of manifestation, and the useful strategies for 43 treatment. T2D is considered to develop due to insulin resistance rather than initial beta-cell loss. 44 However, to compensate for the imbalance, the beta-cells produce more insulin but then, after 45 years of hypersecretion, the pool of beta-cells is depleted by up to $65 \%$ in some cases. As a consequence, this group of T2D patients also needs exogenous insulin administration (Butler et al., 2003; Eckel et al., 2011). However, exogenous control of insulin dosage cannot compensate for the sensitive adjustment normally made by beta-cells. This often leads to hyper- or hypoglycemia with corresponding complications increasing with the time. Hyperglycemia increases the development and progression of microvascular complications such as retinopathy, nephropathy, and neuropathy (Gibbons, 2020; Williams, Nawaz \& Evans, 2020). Furthermore, the most severe complications are those related to hypoglycemia in T1D patients, resulting in neurocognitive dysfunction (Kodl $\&$ Seaquist, 2008). Thus, recovery of the pool of beta-cells is an attractive strategy for treating patients with diabetes (Figure 1). Currently, only surgical islet transplantation provides such an opportunity (Shapiro, Pokrywczynska \& Ricordi, 2017; Matsumoto \& Shimoda, 2020). Islet transplantation has been developed mainly for T1D patients and involves both transfusion into the portal vein and embolization within the liver, and allows the avoidance of complications related to whole organ transplantation. However, such an approach is complicated by the limited source of donor tissue available and by immune rejection, requiring immuno-suppression therapy (Posselt et al., 2010). Furthermore, there are no approved methods in regenerative medicine that can address the specific characteristics required of beta-cells. Our current understanding of lesion mechanisms in beta-cells is based on rodent studies. Although it appears that human pancreas does show a corresponding lack of regeneration capacity under systemic disorders. Therefore the translation of these observation to human betacells should be handled with caution (Zhou \& Melton, 2018). Indeed, a comprehensive analysis of a diverse array of animal models and human cell cultures might be fruitful in initiating new advances in regenerative medicine.

\section{Survey methodology}

The purpose of this article is to present a comprehensive review of the literature regarding recent methods of regenerative medicine in diabetes mellitus. To that aim, we performed PubMed searches for such keywords and terms as "beta-cells", "pluripotent stem cells", "3D culturing", "transdifferentiation", and "diabetes mellitus" among others. We then analyzed articles from Q1 journal ranking quartiles within the subdiscipline, using the SJR citations referenced. Although this is a comprehensive review, it is not exhaustive. It should be noted that we focused particularly on the limitations of the current methods, as solutions to these problems should help progress the development of regenerative medicine. However, it must be 
79

80

81

82

83

84

85

86

87

88

89

90

91

92

93

94

95

96

97

98

99

100

101

102

103

104

105

106

107

108

109

110

111

112

113

114

115

116

117

118

remembered, that the question regarding the problems underlying beta-cell preservation remains open and needs further investigation.

\section{CHARACTERISTICS OF BETA-CELLS}

Beta-cells are one of the five cell types that form the islets of Langerhans, the hormoneproducing structures of the pancreas. The islets are heterogeneously distributed in the pancreas and, according to recent studies, have a variety of content and functions. Patients with removal of the pancreatic tail showed increased glucose level indicators post-operatively than did patients with pancreatic head ectomy (Menge et al., 2009). Menge et al. showed, that the number of islets in the tail is greater than that in the head of the pancreas Such a difference can be explained by the distinct embryogeneses of the pancreas head and tail: while the head originates from the dorsal and ventral pancreatic bud, the body and tail are formed only from the ventral pancreatic bud. (Pandol, 2010). That also influences the heterogeneity of the beta-cells, as has been confirmed by single-cell RNA-seq technologies. Recent studies have revealed two subpopulations of beta-cells with distinct molecular, physiological, and ultrastructural features (Bader et al., 2016; Baron et al., 2016). However, further investigations of their roles in diabetes are needed.

Beta-cell deficiency affects the ratios of other cell types in the islets of Langerhans. There are complex cell-to-cell interactions in the islets, resulting in a unique cytoarchitectural structure. Recent studies with beta-cell culturing in three-dimensional (3D) gels have shown the importance of such interactions (Weber, Hayda \& Anseth, 2008; Xu et al., 2020). In these experiments the 3D gel contained extracellular matrix (ECM) proteins and directly influenced cytoskeletal organization, promoting beta-cell maturation and insulin secretion. As is known, diabetes patients exhibit dramatic changes not only in their hormone levels but also in the structure and intrinsic cell communications within the pancreas. In this case, 3D hydrogel cultures are more promising for diabetes treatment than 2D ones.

In T1D the deficiency of beta-cells is a result of immune attack by T-lymphocytes. Nakayama et al. showed that in the NOD mouse model the insulin epitope is a prime target for effector Tlymphocytes: B:9-23 peptide promotes the development of insulin autoantibodies (Nakayama et al., 2007). But it is not only insulin production that is affected by this T-lymphocyte targeting; due to the effect of epitope spreading, the islet-specific glucose-6-phosphatase catalytic subunitrelated protein (IGRP) is also targeted after insulin (Prasad et al., 2012)).IGRP is a multicomponent integral membrane system that plays a crucial role in the terminal step of the gluconeogenic and glycogenolytic pathways, catalyzing the hydrolysis of glucose-6-phosphate. Krishnamurthy et al. demonstrated that the development of an autoimmune responses to multiple autoantigens increases the progression of T1D (Krishnamurthy et al., 2006).

Herewith, histological analyzes show that the destruction of the beta-cells has a lobular character, and some of the islets show insulin staining (Gianani et al., 2010) This can be explained by the above-mentioned difference in the beta-cell populations. 
119

120

121

122

123

124

125

126

127

128

129

130

131

132

133

134

135

136

137

138

139

140

141

142

143

144

145

146

147

148

149

150

151

152

153

154

155

156

157

158

BETA-CELL SOURCES IN VIVO

To date, the existence of a definite native source for beta-cell regeneration remains in dispute (Teta et al., 2007). There are at least four suggested sources: beta-cells themselves, acinar cells, ductal cells, and alpha-cells.

Adult pancreatic beta-cells are formed mainly by self-duplication, this evidence having been demonstrated using a lineage tracing approach (Dor et al., 2004). Using a mouse model, Dor et al. showed that at least $85 \%$ of new beta-cells were formed from pre-existing beta-cells. This conclusion applied to both the normal adult pancreas and to pancreas subjected to partial ectomy. However, special circumstances, e.g. pregnancy or diabetes, may activate other sources of betacells. Acinar, ductal and endocrine cells possess Pdx1/Ptf1-positive multipotent pancreatic progenitors during organogenesis. The endocrine specification of these progenitors is initiated by the Neurogenin3 (NEUROG3) and neurogenic differentiation 1 (NEUROD1) transcription factors (TFs), while the late stages of maturation of beta-cells is regulated by TFs including Vmaf musculoaponeurotic fibrosarcoma oncogene homolog A (MAFA), V-maf musculoaponeurotic fibrosarcoma oncogene homolog B (MAFB), paired box gene 6 (PAX6), and estrogen-related receptor gamma (ESRRG) (Zhu et al., 2017). Thus, alterations in the ectopic expression of key transcription factors can change the fate of pancreatic cells (Table 1). Embryonic ducts give rise to both differentiated endocrine and duct cells but once the pancreatic duct epithelium acquires a differentiated phenotype it does not contribute significantly to new beta-cells. Lineage-tracing studies by several research groups have shown that the ducts in adults do not appear to be a source of beta-cells (Kopinke \& Murtaugh, 2010; Kopp et al., 2011).

However, lineage-tracing analysis in studies by Inada et al. and Zhang et al. did demonstrate that such a possibility exists (Inada et al., 2008; Zhang et al., 2016). Such discrepancies may be explained by heterogeneity in the duct cell populations and of the different gene regions that were used for tracing.

Dirice et al. showed a contribution of duct cells to the compensatory beta-cell pool by neogenesis during pregnancy, with increased insulin demand (Dirice et al., 2019). Furthermore, using an injury model of the pancreas in mice, $\mathrm{Xu}$ et al. also revealed the neogenesis of beta-cells from duct cells (Xu et al., 2008). The injury involved partial duct ligation with the restriction of digestive enzyme drainage from the exocrine pancreas into the duodenum. This ligation caused degeneration of the acinar cells and the extensive proliferation of duct cells. $\mathrm{Xu}$ et al. found that such ducts not only highly express NGN3, but also have the ability to form islets of Langerhans in NGN3-deficient embryos. This confirmed NGN3 as a key regulator both in beta-cell neogenesis and in their embryonic development.

Acinar cells are the most abundant type of exocrine pancreatic cells, producing enzymes for food digestion. They could also be a source of beta-cells, but attempts to prove this suggestion by lineage tracing methods in mouse models have been unsuccessful (Desai et al., 2007), indicating that acinar cells do not normally transdifferentiate into beta-cells. Nonetheless, by exhibiting significant transcriptional plasticity during culture, acinar cells remain an attractive source for in vitro beta-cell generation. Thus, Pan et al. showed the ability of acinar-to-beta-cell conversion, 
159 including an intermediate step with pancreatic multipotent progenitor cells (Pan et al., 2013).

160 Clayton et al. performed direct reprogramming of acinar cells on a transgenic mouse by the

161 virus-based induction of PDX1, MAFA, and NGN3 (Clayton et al., 2016) Another important

162 output from their study concerns the impact of inflammation on the reprogramming result.

163 Marked inflammation processes promote an acinar-to-ductal cell transition and inhibit the

164 number of beta-cells.

165 Despite the fact, that alpha and beta-cells play antagonistic roles, alpha-cells seem to be the most 166 promising source for beta-cell recovery, since they are the second-largest endocrine cell group in 167 the pancreas and have tight connections with beta-cells. Several studies have demonstrated the 168 possibility of alpha-to-beta transdifferentiation (Thorel et al., 2010; Bru-Tari et al., 2019). While 169 the experiments include different diabetes modeling methods in mice, their results are united by 170 the conclusion that the conversion can occur with immature alpha-cells. Only this limited 171 population has the necessary plasticity for transition in the lack of insulin. To force this transition 172 a Collombat group applied small molecules mimicking the effects of the ectopic expression of 173 Pax4 and inhibiting Arx in alpha-cells (Ben-Othman et al., 2017). Small molecules refer to 174 organic compounds with low molecular weight ( $<900$ daltons), that may regulate biological 175 process. A Collombat group identified that gamma-aminobutyric acid (GABA) induces alpha-to176 beta transdifferentiation (Table 1). GABA is synthesized in beta-cells and has previously been 177 described as a regulator of hormone secretion and as a signaling molecule in islet cell 178 communication (Franklin \& Wollheim, 2004). Notably, GABA-mediated transdifferentiation 179 was limited by the number of alpha-cells, which decreased in line with the concomitant increase 180 in numbers of beta-cells.

181 To sum up: pre-existing beta-cells appear to be the principal in vivo source of new beta-cells, 182 while the contribution of other sources is less significant. However, several groups have 183 demonstrated the feasibility of artificially inducing transdifferentiation of pancreatic non-beta184 cells in vivo (Zhou et al., 2008; Li et al., 2014). Meanwhile, as the induced beta-cells are located 185 in the native milieu, researchers have an opportunity for the direct comparison of endogenous 186 and induced beta-cells. Despite promising results, there are some points that need further 187 investigation. For instance, Zhou et al. observed a lack of organization of the induced beta-cells 188 that can impair their function. Such result may be explained by DNA methylation, which pre189 existed in the regulatory elements of the non-beta-cells. Detailed epigenetic maps allow this 190 problem to be overcome and a more targeted effect to be obtained (Gifford \& Meissner, 2012). 191 There are also many problems with integrating viral delivery, and these can be even more 192 complicated in vivo, resulting in off-target effects.

193

\section{BETA-CELL SOURCES IN VITRO}

195

196

197

198 Ex-vivo generation of beta-cells remains an attractive strategy in regeneration medicine, however, the differentiated cells normally have low proliferation activity. For these purposes, different agonists have been tested: nutrients, growth factors, intracellular signaling molecules, and small molecules (Huang \& Chang, 2014). Currently, however, the proliferation of beta-cells 
199 in tissue culture results in a loss of the beta-cell phenotype, making it difficult to use them for

200 diabetes therapy (Efrat, 2008). A proposed method of redifferentiation showed only low

201 efficiency (Kayali et al., 2007).

202 To date, the most promising approaches for beta-cell generation include the differentiation of

203 stem cells and the generation of beta-cells while bypassing pluripotency (Table 2).

204 1. ESC differentiation

205 The differentiation of ESCs into beta-cells in vitro was developed in the early 2000s (Keller, 206 1995). The Baetge group developed the first directed differentiation protocol and identified the 207 main principles for stem cell differentiation into beta-cells (D'Amour et al., 2006). The first step 208 in the differentiation of ESCs is a very critical stage in the formation of the definitive endoderm 209 (DE) lineage (Baetge, 2008). This step is essential for the successful differentiation of the 210 pancreatic lineage. The second step involves foregut endoderm formation and requires the 211 addition of transforming growth factor-beta. Retinoic acid application is essential for the third 212 step of the pancreas specification. Retinoic acid contributes to the efficient transition to the 213 pancreatic lineage and prevents the differentiation of the pancreatic endoderm into endocrine 214 cells. During the fourth step, foregut endoderm cells are recruited to the pancreatic and endocrine 215 lineages. These cells have a high expression of PDX1 and transient expression of NGN3. During 216 the fifth step the range of different hormones normally produced by endocrine cells start to be 217 secreted. The ratio of beta-cells generated depends on the characteristics of the cell culture media 218 and the success of the previous stages.

219 Each step requires strict monitoring of the expression of marker genes by immunohistochemical 220 analysis, flow cytometry, and RT-PCR. Such an approach is essential for determining the 221 homogeneity of the phenotypes and the efficiency of the multiple differentiation steps. However, 222 even rigorous monitoring cannot guarantee the absence of teratoma formation from the 223 undifferentiated ESCs. There is still a need for developing the standards needed in ESC therapy 224 to provide safety (Hentze et al., 2009)

225 2. iPSC differentiation

226 The limited sources of ESCs and allograft rejection of transplanted ESCs have forced a search 227 for alternative methods of beta-cell regeneration. The discovery of induced pluripotent cells 228 derived from human somatic cells has initiated a new chapter in regenerative medicine.

229 The use of iPSCs has allowed the generation of patient-specific beta-cells for autologous 230 transplantation, with adult fibroblasts being frequently used for this process, representing an 231 almost unlimited source for the generation of iPSCs.

232 Most of such iPSCs lines are made using retrovirus vectors that integrate the reprogramming 233 factors involved in stem cell pluripotency. Such an approach is associated with the risk of 234 tumorigenesis. Therefore the latest methods of iPSC generation involve non-integrating gene 235 delivery, such as the Sendai virus, plasmid transfection, the piggyback transposon system, and 236 minicircle vectors.

237 Recent studies have introduced a new strategy for the direct differentiation of iPSCs to 238 pancreatic beta-cells (Hogrebe et al., 2020). The principle is based on cytoskeleton 
239

240

241

242

243

244

245

246

247

248

249

250

251

252

253

254

255

256

257

258

259

260

261

262

263

264

265

266

267

268

269

270

271

272

273

274

275

276

277

278

reorganization, whereby F-actin is depolymerized. It has been shown that latrunculin A and B guide stem cell differentiation towards a beta-cell fate, shortening the time for endocrine transcription factor expression and overcoming the requirement for $3 \mathrm{D}$ culture (Table 1). These advances bring iPSC technology to the top of the most promising regeneration approaches. However, the risks found with teratoma formation from ESCs, for instance, also exist for iPSCs.

3. Mature cell transdifferentiation

The direct conversion of adult cells without the establishment of a pluripotency step would allow avoiding oncological complications. Early studies have revealed a capacity of pancreatic cells, such as ductal, acinar and non-beta endocrine cells to transdifferentiate into beta-cells by using a specific combination of multiple factors (PDX1, NGN3, and MAFA predominantly) (Baeyens et al., 2005; Minami et al., 2005).

While the pancreatic cells have increased capacity for being reprogrammed into beta-cells, there are still difficulties with culturing sufficient quantities of these cells. Besides, the pancreas is a retroperitoneal organ and is very difficult to assess for biopsies.

Thus, there is a need to search for alternative sources for transdifferentiation: ones that are both easy to culture and biopsy. In this case, human fibroblasts appear particulary promising. It has previously been shown that fibroblasts can be directly reprogrammed into neurons, hepatocytes, or cardiomyocytes (Zhu, Wang \& Ding, 2015; Babos \& Ichida, 2015; Chen et al., 2017). In these studies, the researchers applied a cell-activation and signaling-directed (CASD) strategy. In the first step of this approach, a key set of reprogramming factors (transcription factors or small molecules) turn the fibroblasts into a plastic and unstable state. During this step, the cells have a transient expression of pluripotency. However, several studies have shown, that such transient expression of the pluripotency genes does not necessarily mean a transient establishment of the pluripotency intrinsic for iPSCs (Maza et al., 2015; De Los Angeles et al., 2015). Margariti et al., in their article, termed these "partial-iPS (PiPS) cells" and showed, that PiPS cells in this state did not form tumors in vivo (Margariti et al., 2012) To provide an appropriate level of safety for the medical use of CASD technology, several researchers have suggested a CA step, using small molecules instead of transgenic reprogramming factors (Table 1) (Hu et al., 2015; Li et al., 2015). Furthermore, such non-integrating methods make the CA step faster and more effective compared with manipulations of the genome. However, the low reproducibility of the protocols involving small molecules limits their application (Kim, Jeong \& Choi, 2020).

Subsequent treatment with sequential combinations of growth factors and soluble lineagespecific signals proceed to the second step of the CASD approach. During the lineage-specific SD step the unstable intermediate population of cells generates progenitors of the desired cell line.

Currently, CASD technology has great potential in regenerative medicine and has raised hopes for its clinical application. However, further investigations are needed for comprehensive determination of the CA step and for obtaining homogeneity of cell conversion during the SD step.

4. Adult stem cell differentiation 
279 One other promising source for beta-cell generation is adult stem cells (ASCs), and this has 280 attracted close attention in recent years. ASCs, also called somatic stem cells, are located in 281 specialized niches and serve for maintaining tissue homeostasis. Such niches with ASCs have 282 been found in numerous tissues and organs, including the pancreas. However, these populations 283 are rare and cannot provide complete regeneration of the beta-cell mass in patients with systemic 284 endocrine disorder. Thus, various research groups have suggested proliferating ASCs in vitro 285 (Gurusamy et al., 2018). Mitutsova et al. have shown, that non-adherent muscle-derived adult 286 stem cells (MDSCs) have the potential to differentiate into beta-cells during in vitro culturing 287 (Mitutsova et al., 2017). In their experiment a multipotent stem cell population isolated from 288 adult skeletal muscle was able to form islet-like cell clusters. Furthermore, adult MDSCs injected into hyperglycemic diabetic mice, successfully differentiated into beta-cells in vivo and contributed to reducing the glucose levels. Despite these promising results, the application of adult MDSCs is restricted by complications of the muscle biopsy, which requires several areas of expertise and optimal cryoprocessing of the fresh specimens. In the light of this, bone-marrow and adipose-derived stem cells (BMDSCs and ADSCs) are more readily available (Trivedi et al., 2008; Phadnis et al., 2011). BMDSCs contain two distinct populations: hematopoietic stem cells and mesenchymal stem cells, of which the mesenchymal stem cell population is more successful in adopting a pancreatic fate (Carlsson et al., 2015). Zhao et al. have identified a novel cell population of monocytes from adult human blood that can differentiate into efficient insulinproducing cells in vitro. These peripheral blood mononuclear cells express ESC transcription factors along with the hematopoietic markers (Zhao et al., 2007). The authors showed that, after 30 days of culturing, these mononuclear cells began to express the insulin gene transcription factors MafA and Nkx6.1 and to produce insulin.

ADSCs have certain advantages compared with BMDSCs (Takahashi et al., 2019). First the isolation of adipose-derived stem cells presents less harvesting difficulty(Wang et al., 2018). Second, ADSCs have been shown to have a higher differentiative potential, while BMDSCs tend toward osteogenesis and chondrogenesis (Dmitrieva et al., 2012). The third advantage involves the immunosuppressive capacity of ADSCs. It has been shown that ADSCs do not excite alloreactivity of incompatible lymphocytes, suppressing the mixed lymphocyte reaction by inducing the expansion of Tregs (Puissant et al., 2005). Furthermore, ADSCs contribute to an increase in anti-inflammatory cytokines (Kocan et al., 2017) However, the increased expression of inflammatory cytokines and long-term fibrinolytic modifications in T2DM patients might impair the efficiency of therapy by adipose-derived stem cells (Serena et al., 2016; Brovkina et al., 2019).

Urine-derived stem cells (USCs) can also be applied as a potential stem cell source for diabetes therapy (Zhao et al., 2018). The advantages of USC use consists in their noninvasive isolation and expandable and simple methods of culturing. However, Zhao et al. noticed that USCs are useful only in compensating for minor apoptosis of beta-cells, but not in cases of extensive depletion as in T1D patients. 
318 One of the major problem of the application of ASCs is their limited transdifferentiation 319 efficiency, which affects from 5 to $25 \%$ of the cells (Sharma \& Rani, 2017). Another problem is 320 the low level of insulin secreted by differentiated ASCs and their limited lifespan without 321 stemness. Nonetheless, despite these current limitations the ASC approach has undeniable

322

323

324

325

326

327

328

329

330

331

332

333

334

335

336

337

338

339

340

341

342

343

344

345

346

347

348

349

350

351

352

353

354

355

356

357 advantages over using iPSCs since it presents a lower risk of generating teratomas and autoimmune responses in vivo.

\section{METHODS FOR BETA-CELL PRESERVATION}

The protection of beta-cells is no less important than their generation. This is an especially significant issue in the early phases of T1D or T2D when beta-cell mass is maximal. The common strategy for T2D treatment is targeting insulin-resistance and beta-cell dysfunction. Metformin and PPAR-gamma agonists are applied to decrease the insulin resistance, while sulphonylureas and glinides enhance secretion by the beta-cells. Some of the drugs effective in T2D treatment have also been considered for T1D patients. For example, verapamils, calcium channel blockers, and glucagon-like peptide-1 receptor agonists decrease beta-cell injury and exert beta cell-protective effects in experimental models of T1D (Chen et al., 2008; Lotfy et al., 2014). However, due to the immunogenic development of T1D, immunotherapy for beta-cells is more effective. Immunotherapy of T1D has two main approaches: the first is manipulation of the autoimmune response independently of beta-cell specificity, while the second uses beta-cell antigen-specific strategies. The limited specificity of the first approach can suppress acquired immunity. In this case, antibody-based therapy is more promising. However, current studies of anti-CD3 monoclonal antibodies show, that the protection of the residual beta-cell mass is shortterm and can result in cytokine release and unwanted inflammation (Chatenoud \& Bluestone, 2007, p. 3).

In regenerative medicine, the protection of generated beta-cells is also a paramount aim. However, first of all, we have to define what exactly should be protected - the beta-cell mass or its function. Beta-cells have different populations and some of them survive during immune attack (Keenan et al., 2010). Further investigation has revealed, that the surviving populations are of lower granularity cells with stem-like features and increased rates of proliferation, but they have a lower insulin content (Rui et al., 2017). Talchai et al. suggested these characteristics are due to beta-cell dedifferentiation (Talchai et al., 2012). Thus, the reemergence of endocrine progenitor-like cells results in beta-cell dysfunction. In such cases the beta-cells maintain the expression of marker genes, like Pdx1 and MafA, but adopt a dedifferentiated fate and do not release insulin. Recent work by Lee et al. confirms that dedifferentiated beta-cells exhibit reduced levels of beta-cell autoantigens and increased expression of immune inhibitory markers (Lee et al., 2020). Evidently, the preservation of beta-cell function and their mature populations should be a priority.

There are two main approaches that enable the protection of transplanted cells from the immune system without the need for systemic immunosuppression: islet encapsulation and "open" islet transplantation(Korsgren, 2017; Peloso et al., 2018; Ernst et al., 2019). The encapsulation strategy uses a biocompatible membrane that wraps the beta-cells. Such containers permit the 
358

359

360

361

362

363

364

365

366

367

368

369

370

371

372

373

374

375

376

377

378

379

380

381

382

383

384

385

386

387

388

389

390

391

392

393

394

395

396

397

diffusion of oxygen and nutrients while protecting against larger molecules, including antibodies. This strategy has several advantages. Since the mature beta-cells are more fragile, immature cells are preferable for transplantation. Encapsulation both isolates immature cells from stress conditions and protects them from the host immune system. A further advantage of encapsulation is the possibility of immediate removal of specific containers if tumorigenesis is detected.

Despite some promising results, current encapsulation technology has serious limitations. One of these is a difference in the kinetics of glucose and insulin diffusion compared with native islets (Korsgren, 2017). Insulin secretion in encapsulated beta-cells is delayed, leading to a risk of persistence of hypoglycemia. Another problem is of limited oxygen and nutrient delivery to the encapsulated cells due to deficiencies in the vascularization processes (Rafael et al., 2000). A third problem is the process of fibrosis that starts with recognition of nonspecific protein adsorption and leads to the formation of a fibrotic capsule around the implant. Nanotechnology provides opportunities to overcome or mitigate the aforementioned problems. A variety of nanoscale chemical, physical, and biological properties of the interfacing polymers has been shown to modulate the immune response and to enhance the vascularization processes. In this case, the composition of the polymer plays a significant role in the biocompatibility. Hydrogels and alginate matrix are commonly used in encapsulation technology. The modification of these polymers with certain compounds and proteins both decreases the magnitude of fibrosis and promotes vascularization. Thus, polyethylene glycol (PEG) with affinity peptides has been shown to significantly reduce the level of chemokines, thereby contributing to a reduction of inflammation (Lin et al., 2010). Hemoglobin-conjugated hydrogels improve the islet oxygenation, while crosslinked antioxidant enzymes can protect the hemoglobin from hypoxic and free radical stress (Nadithe, Mishra \& Bae, 2012). Increasing vascularization is a challenging task, because this process is accompanied by inflammation, and this negatively influences islet survival. The current strategy for solving this problem includes modification of the surface roughness and porosity of the polymers, combined with anchoring vascular endothelial growth factor to their surfaces. Collagens, fibronectin, and laminin in the islet coat conduce the vascularity of implanted islets by mimicking the natural islet matrix (Salvay et al., 2008). Vlahos et al. engineered submillimeter collagen cylinders (modules) coated with endothelial cells, and these promoted islet vascularization and resulted in a proangiogenic M2-like macrophage response (Vlahos, Cober \& Sefton, 2017). Also, the larger pores were able to act as effective scaffolding for the vasculature. Brauker et al. demonstrated that a $0.8-8-\mu \mathrm{m}$ pore size allowed the penetration of host blood vessels into the device if the large-pore membrane was laminated to a smaller-pore inner membrane (Brauker et al., 1995).

Finally, the layer-by-layer method allows the engineering of islet polymer films with versatile functions and optimal composition, thickness, and mechanical properties (Wilson et al., 2011). In contrast to the encapsulation strategy "open" islet transplantation permits host interaction with the implanted material. The stem cell educator therapy proposed by Zhao et al. reverses autoimmunity and allows the preservation of transplanted islets (Zhao et al., 2012; Zhao, 2012). This therapy is based on cord blood-derived multipotent stem cells being co-cultured with the 
398

399

400

401

402

403

404

405

406

407

408

409

410

411

412

413

414

415

416

\section{Conclusions \\ Conclusions}

418

419

420

421

422

423

424

425

426

427

428

429

430

431

432

433

434

435

436

437

patient's lymphocytes in a closed-loop system. After this, the educated lymphocytes are separated and returned to the patient's circulation. The authors demonstrated that stem cell educator therapy increases in the number of Tregs and restores the cytokine balance (Zhao et al., 2012). Peripheral blood-derived insulin-producing cells are an alternative source that display the characteristics of islet beta-cell progenitors and therefore can also provide a potential resource for educator therapy (Zhao et al., 2007).

The application of stem cells may also play a part in the protection of the transplanted beta-cells. Such an impact is due to the ability to induce the proliferation of Tregs and the promotion of neovascularization (Caballero et al., 2007; Chen et al., 2020). Thus, a hybrid transplantation, which combined islet transplantation with mesenchymal stem cells, was shown to improve graft function (Figliuzzi et al., 2009). Furthermore, in vitro co-culturing of an islet graft with mesenchymal stem cells contributed to oxygenation and nutrient supply, as well as decreasing the levels of inflammatory cytokines (Arzouni et al., 2017). Therefore, co-culturing appears to increase both the survival of the beta-cells and islet quality.

Summing up, the development and combining of new technologies in regenerative medicine provides a means to overcome the very real complications of beta-cell recovery. However, despite the promising results, the effectiveness and reproducibility of the suggested solutions need further verification.

These days regenerative medicine is advancing rapidly, breaking new ground. iPSC-technology is replacing ESCs, to provide an almost unlimited source for the generation of desired autologous cell lines. Currently, stem cell technologies are taking the lead in the regeneration of beta-cells, however, there are certain risks due to manipulations of the genome and the capacity of undifferentiated cells for forming teratomas. To overcome these limitations, the transient introduction of RNAs, recombinant proteins, or chemical mimics can substitute virus-mediated introduction. Meanwhile, the direct conversion of mature cells or the differentiation of adult stem cells can reduce the risk of teratoma development. Thus, the current trends of regenerative medicine are aiming towards safety and immune-compatibility.

However, despite the substantial success of regenerative medicine overall, there are still many whitespaces in diabetes treatment when using beta-cells. Without a primary determination of the diversity and functions of different beta-cell populations, current technologies for beta-cell reproduction represent a colossus with feet of clay and will continue to have limitations. Epitranscriptome modifications also require further investigations, especially for transdifferentiation approaches, since most of the studies suggest that the newly generated betacells retain the epigenomic landscape of the initial cell line. Evidently, beta-cell preservation remains a stumbling block in diabetes treatment. Finding a solution to this problem represents the core task both for treating early stage patients and for patients with a total loss of beta-cells. 


\section{Acknowledgements}

439 This work was supported by grant №075-15-2019-1789 from the Ministry of Science and Higher 440 Education of the Russian Federation, allocated to the Center for Precision Genome Editing and

441 Genetic Technologies for Biomedicine.

442

443 References

444 Arzouni AA, Vargas-Seymour A, Rackham CL, Dhadda P, Huang G-C, Choudhary P, Nardi N,

445

446

447

448

449

450

451

452

453

454

455

456

457

458

459

460

461

462

463

464

465

King AJF, Jones PM. 2017. Mesenchymal stromal cells improve human islet function through released products and extracellular matrix. Clinical Science (London, England: 1979) 131:2835-2845. DOI: 10.1042/CS20171251.

Babos K, Ichida JK. 2015. Small Molecules Take a Big Step by Converting Fibroblasts into Neurons. Cell Stem Cell 17:127-129. DOI: 10.1016/j.stem.2015.07.018.

Bader E, Migliorini A, Gegg M, Moruzzi N, Gerdes J, Roscioni SS, Bakhti M, Brandl E, Irmler M, Beckers J, Aichler M, Feuchtinger A, Leitzinger C, Zischka H, Wang-Sattler R, Jastroch M, Tschöp M, Machicao F, Staiger H, Häring H-U, Chmelova H, Chouinard JA, Oskolkov $\mathrm{N}$, Korsgren O, Speier S, Lickert H. 2016. Identification of proliferative and mature $\beta$ cells in the islets of Langerhans. Nature 535:430-434. DOI: 10.1038/nature18624.

Baetge EE. 2008. Production of $\beta$-cells from human embryonic stem cells. Diabetes, Obesity and Metabolism 10:186-194. DOI: 10.1111/j.1463-1326.2008.00956.x.

Baeyens L, De Breuck S, Lardon J, Mfopou JK, Rooman I, Bouwens L. 2005. In vitro generation of insulin-producing beta cells from adult exocrine pancreatic cells. Diabetologia 48:4957. DOI: 10.1007/s00125-004-1606-1.

Baron M, Veres A, Wolock SL, Faust AL, Gaujoux R, Vetere A, Ryu JH, Wagner BK, Shen-Orr SS, Klein AM, Melton DA, Yanai I. 2016. A Single-Cell Transcriptomic Map of the Human and Mouse Pancreas Reveals Inter- and Intra-cell Population Structure. Cell systems 3:346-360.e4. DOI: 10.1016/j.cels.2016.08.011.

Ben-Othman N, Vieira A, Courtney M, Record F, Gjernes E, Avolio F, Hadzic B, Druelle N, Napolitano T, Navarro-Sanz S, Silvano S, Al-Hasani K, Pfeifer A, Lacas-Gervais S,

Peer) reviewing PDF | (2020:04:48390:2:0:NEW 17 Jul 2020) 
466

467

468

469

470

471

472

473

474

475

476

477

478

479

480

481

482

483

484

485

486

487

488

489

490
Leuckx G, Marroquí L, Thévenet J, Madsen OD, Eizirik DL, Heimberg H, Kerr-Conte J, Pattou F, Mansouri A, Collombat P. 2017. Long-Term GABA Administration Induces Alpha Cell-Mediated Beta-like Cell Neogenesis. Cell 168:73-85.e11. DOI: 10.1016/j.cell.2016.11.002.

Brauker JH, Carr-Brendel VE, Martinson LA, Crudele J, Johnston WD, Johnson RC. 1995. Neovascularization of synthetic membranes directed by membrane microarchitecture. Journal of Biomedical Materials Research 29:1517-1524. DOI: 10.1002/jbm.820291208.

Brovkina O, Nikitin A, Khodyrev D, Shestakova E, Sklyanik I, Panevina A, Stafeev I, Menshikov M, Kobelyatskaya A, Yurasov A, Fedenko V, Yashkov Y, Shestakova M. 2019. Role of MicroRNAs in the Regulation of Subcutaneous White Adipose Tissue in Individuals With Obesity and Without Type 2 Diabetes. Frontiers in Endocrinology 10:840. DOI: 10.3389/fendo.2019.00840.

Bru-Tari E, Cobo-Vuilleumier N, Alonso-Magdalena P, Dos Santos RS, Marroqui L, Nadal A, Gauthier BR, Quesada I. 2019. Pancreatic alpha-cell mass in the early-onset and advanced stage of a mouse model of experimental autoimmune diabetes. Scientific Reports 9:1-12. DOI: 10.1038/s41598-019-45853-1.

Butler AE, Janson J, Bonner-Weir S, Ritzel R, Rizza RA, Butler PC. 2003. Beta-cell deficit and increased beta-cell apoptosis in humans with type 2 diabetes. Diabetes 52:102-110. DOI: $10.2337 /$ diabetes.52.1.102.

Caballero S, Sengupta N, Afzal A, Chang K-H, Calzi SL, Guberski DL, Kern TS, Grant MB. 2007. Ischemic Vascular Damage Can Be Repaired by Healthy, but Not Diabetic, Endothelial Progenitor Cells. Diabetes 56:960-967. DOI: 10.2337/db06-1254.

Carlsson P-O, Schwarcz E, Korsgren O, Blanc KL. 2015. Preserved $\beta$-Cell Function in Type 1 Diabetes by Mesenchymal Stromal Cells. Diabetes 64:587-592. DOI: 10.2337/db140656. 
491 Chatenoud L, Bluestone JA. 2007. CD3-specific antibodies: a portal to the treatment of

492

493

494

495

496

497

498

499

500

501

502

503

504

505

506

507

508

509

510

511

512

513

514

515 autoimmunity. Nature Reviews. Immunology 7:622-632. DOI: 10.1038/nri2134.

Chen J, Saxena G, Mungrue IN, Lusis AJ, Shalev A. 2008. Thioredoxin-interacting protein: a critical link between glucose toxicity and beta-cell apoptosis. Diabetes 57:938-944. DOI: $10.2337 / \mathrm{db} 07-0715$.

Chen Q-H, Wu F, Liu L, Chen H, Zheng R-Q, Wang H-L, Yu L-N. 2020. Mesenchymal stem cells regulate the Th17/Treg cell balance partly through hepatocyte growth factor in vitro. Stem Cell Research \& Therapy 11:91. DOI: 10.1186/s13287-020-01612-y.

Chen Y, Yang Z, Zhao Z-A, Shen Z. 2017. Direct reprogramming of fibroblasts into cardiomyocytes. Stem Cell Research \& Therapy 8. DOI: 10.1186/s13287-017-0569-3.

Clayton HW, Osipovich AB, Stancill JS, Schneider JD, Vianna PG, Shanks CM, Yuan W, Gu G, Manduchi E, Stoeckert CJ, Magnuson MA. 2016. Pancreatic Inflammation Redirects Acinar to Beta Cell Reprogramming. Cell reports 17:2028-2041. DOI: 10.1016/j.celrep.2016.10.068.

D'Amour KA, Bang AG, Eliazer S, Kelly OG, Agulnick AD, Smart NG, Moorman MA, Kroon E, Carpenter MK, Baetge EE. 2006. Production of pancreatic hormone-expressing endocrine cells from human embryonic stem cells. Nature Biotechnology 24:1392-1401. DOI: $10.1038 / n b t 1259$.

De Los Angeles A, Ferrari F, Xi R, Fujiwara Y, Benvenisty N, Deng H, Hochedlinger K, Jaenisch R, Lee S, Leitch HG, Lensch MW, Lujan E, Pei D, Rossant J, Wernig M, Park PJ, Daley GQ. 2015. Hallmarks of pluripotency. Nature 525:469-478. DOI: 10.1038/nature15515.

Desai BM, Oliver-Krasinski J, De Leon DD, Farzad C, Hong N, Leach SD, Stoffers DA. 2007. Preexisting pancreatic acinar cells contribute to acinar cell, but not islet beta cell, regeneration. The Journal of Clinical Investigation 117:971-977. DOI: $10.1172 / \mathrm{JCl} 29988$. 
516 Dirice E, De Jesus DF, Kahraman S, Basile G, Ng RWS, El Ouaamari A, Teo AKK, Bhatt S, Hu 517 J, Kulkarni RN. 2019. Human duct cells contribute to $\beta$ cell compensation in insulin $518 \quad$ resistance. JCl Insight 4. DOI: 10.1172/jci.insight.99576.

519 Dmitrieva RI, Minullina IR, Bilibina AA, Tarasova OV, Anisimov SV, Zaritskey AY. 2012. Bone 520 marrow- and subcutaneous adipose tissue-derived mesenchymal stem cells: differences

521

522

523

524

525

526

527

528

529

530

531

532

533

534

535

536

537

538

539

540

541 and similarities. Cell Cycle (Georgetown, Tex.) 11:377-383. DOI: 10.4161/cc.11.2.18858.

Dor Y, Brown J, Martinez OI, Melton DA. 2004. Adult pancreatic $\beta$-cells are formed by selfduplication rather than stem-cell differentiation. Nature 429:41-46. DOI: 10.1038 /nature02520.

Eckel RH, Kahn SE, Ferrannini E, Goldfine AB, Nathan DM, Schwartz MW, Smith RJ, Smith SR. 2011. Obesity and Type 2 Diabetes: What Can Be Unified and What Needs to Be Individualized? The Journal of Clinical Endocrinology and Metabolism 96:1654-1663. DOI: 10.1210/jc.2011-0585.

Efrat S. 2008. Ex-vivo Expansion of Adult Human Pancreatic Beta-Cells. The Review of Diabetic Studies : RDS 5:116-122. DOI: 10.1900/RDS.2008.5.116.

Ernst AU, Bowers DT, Wang L-H, Shariati K, Plesser MD, Brown NK, Mehrabyan T, Ma M. 2019. Nanotechnology in cell replacement therapies for type 1 diabetes. Advanced drug delivery reviews 139:116-138. DOI: 10.1016/j.addr.2019.01.013.

Figliuzzi M, Cornolti R, Perico N, Rota C, Morigi M, Remuzzi G, Remuzzi A, Benigni A. 2009. Bone marrow-derived mesenchymal stem cells improve islet graft function in diabetic rats. Transplantation Proceedings 41:1797-1800. DOI: 10.1016/j.transproceed.2008.11.015.

Franklin IK, Wollheim CB. 2004. GABA in the endocrine pancreas: its putative role as an islet cell paracrine-signalling molecule. The Journal of General Physiology 123:185-190. DOI: 10.1085/jgp.200409016. 
542 Gianani R, Campbell-Thompson M, Sarkar SA, Wasserfall C, Pugliese A, Solis JM, Kent SC,

543 Hering BJ, West E, Steck A, Bonner-Weir S, Atkinson MA, Coppieters K, von Herrath M,

544 Eisenbarth GS. 2010. Dimorphic histopathology of long-standing childhood-onset

545 diabetes. Diabetologia 53:690-698. DOI: 10.1007/s00125-009-1642-y.

546 Gibbons CH. 2020. Treatment induced neuropathy of diabetes. Autonomic Neuroscience: Basic

547 \& Clinical 226:102668. DOI: 10.1016/j.autneu.2020.102668.

548 Gifford CA, Meissner A. 2012. Epigenetic Obstacles Encountered By Transcription Factors:

549 Reprogramming Against All Odds. Current opinion in genetics \& development 22:409_

550 415. DOI: 10.1016/j.gde.2012.08.002.

551 Gurusamy N, Alsayari A, Rajasingh S, Rajasingh J. 2018. Chapter One - Adult Stem Cells for

552 Regenerative Therapy. In: Teplow DB ed. Progress in Molecular Biology and

553 Translational Science. Academic Press, 1-22. DOI: 10.1016/bs.pmbts.2018.07.009.

554 Hentze H, Soong PL, Wang ST, Phillips BW, Putti TC, Dunn NR. 2009. Teratoma formation by

555 human embryonic stem cells: Evaluation of essential parameters for future safety

$556 \quad$ studies. Stem Cell Research 2:198-210. DOI: 10.1016/j.scr.2009.02.002.

557 Hogrebe NJ, Augsornworawat P, Maxwell KG, Velazco-Cruz L, Millman JR. 2020. Targeting the 558 cytoskeleton to direct pancreatic differentiation of human pluripotent stem cells. Nature 559 Biotechnology 38:460-470. DOI: 10.1038/s41587-020-0430-6.

560 Hu W, Qiu B, Guan W, Wang Q, Wang M, Li W, Gao L, Shen L, Huang Y, Xie G, Zhao H, Jin Y, 561

562

563 Tang B, Yu Y, Zhao J, Pei G. 2015. Direct Conversion of Normal and Alzheimer's

Huang Y, Chang Y. 2014. Regulation of pancreatic islet beta-cell mass by growth factor and 565 hormone signaling. Progress in Molecular Biology and Translational Science 121:321349. DOI: 10.1016/B978-0-12-800101-1.00010-7. 
567 Inada A, Nienaber C, Katsuta H, Fujitani Y, Levine J, Morita R, Sharma A, Bonner-Weir S. 2008.

568 Carbonic anhydrase II-positive pancreatic cells are progenitors for both endocrine and

569

570 exocrine pancreas after birth. Proceedings of the National Academy of Sciences of the

\section{1}

572

573 United States of America 105:19915-19919. DOI: 10.1073/pnas.0805803105.

Kayali AG, Flores LE, Lopez AD, Kutlu B, Baetge E, Kitamura R, Hao E, Beattie GM, Hayek A.

\section{4}

575

576

577

578

579

580

581

582

583

584

585

586

587

588

589

590

591 2007. Limited capacity of human adult islets expanded in vitro to redifferentiate into insulin-producing beta-cells. Diabetes 56:703-708. DOI: 10.2337/db06-1545.

Keenan HA, Sun JK, Levine J, Doria A, Aiello LP, Eisenbarth G, Bonner-Weir S, King GL. 2010. Residual Insulin Production and Pancreatic $\beta$-Cell Turnover After 50 Years of Diabetes: Joslin Medalist Study. Diabetes 59:2846-2853. DOI: 10.2337/db10-0676.

Keller GM. 1995. In vitro differentiation of embryonic stem cells. Current Opinion in Cell Biology 7:862-869. DOI: 10.1016/0955-0674(95)80071-9.

Kim Y, Jeong J, Choi D. 2020. Small-molecule-mediated reprogramming: a silver lining for regenerative medicine. Experimental \& Molecular Medicine 52:213-226. DOI: 10.1038/s12276-020-0383-3.

Kocan B, Maziarz A, Tabarkiewicz J, Ochiya T, Banaś-Ząbczyk A. 2017.Trophic Activity and Phenotype of Adipose Tissue-Derived Mesenchymal Stem Cells as a Background of Their Regenerative Potential. Available at https://www.hindawi.com/journals/sci/2017/1653254/ (accessed May 29, 2020). DOI: https://doi.org/10.1155/2017/1653254.

Kodl CT, Seaquist ER. 2008. Cognitive Dysfunction and Diabetes Mellitus. Endocrine Reviews 29:494-511. DOI: 10.1210/er.2007-0034.

Kopinke D, Murtaugh LC. 2010. Exocrine-to-endocrine differentiation is detectable only prior to birth in the uninjured mouse pancreas. BMC developmental biology 10:38. DOI: 10.1186/1471-213X-10-38. 
592 Kopp JL, Dubois CL, Schaffer AE, Hao E, Shih HP, Seymour PA, Ma J, Sander M. 2011. Sox9+ 593 ductal cells are multipotent progenitors throughout development but do not produce new 594 endocrine cells in the normal or injured adult pancreas. Development (Cambridge, 595 England) 138:653-665. DOI: 10.1242/dev.056499.

596 Korsgren O. 2017. Islet Encapsulation: Physiological Possibilities and Limitations. Diabetes $597 \quad 66: 1748-1754$. DOI: $10.2337 / \mathrm{db} 17-0065$.

598 Krishnamurthy B, Dudek NL, McKenzie MD, Purcell AW, Brooks AG, Gellert S, Colman PG, 599 Harrison LC, Lew AM, Thomas HE, Kay TWH. 2006. Responses against islet antigens in 600 NOD mice are prevented by tolerance to proinsulin but not IGRP. Journal of Clinical $601 \quad$ Investigation 116:3258-3265. DOI: 10.1172/JCI29602.

602 Lam TKT, Cherney DZI. 2018. Beta cell preservation in patients with type 1 diabetes. Nature 603 Medicine 24:1089-1090. DOI: 10.1038/s41591-018-0144-1.

604 Lee H, Lee Y-S, Harenda Q, Pietrzak S, Oktay HZ, Schreiber S, Liao Y, Sonthalia S, Ciecko AE, 605 Chen Y-G, Keles S, Sridharan R, Engin F. 2020. Beta Cell Dedifferentiation Induced by 606 IRE1a Deletion Prevents Type 1 Diabetes. Cell Metabolism 31:822-836.e5. DOI: $607 \quad$ 10.1016/j.cmet.2020.03.002.

608 Li W, Nakanishi M, Zumsteg A, Shear M, Wright C, Melton DA, Zhou Q. 2014. In vivo 609 610 reprogramming of pancreatic acinar cells to three islet endocrine subtypes. eLife

611 Li X, Zuo X, Jing J, Ma Y, Wang J, Liu D, Zhu J, Du X, Xiong L, Du Y, Xu J, Xiao X, Wang J, 612 Chai Z, Zhao Y, Deng H. 2015. Small-Molecule-Driven Direct Reprogramming of Mouse 613 Fibroblasts into Functional Neurons. Cell Stem Cell 17:195-203. DOI:

$614 \quad$ 10.1016/j.stem.2015.06.003.

615 Lin C-C, Boyer PD, Aimetti AA, Anseth KS. 2010. Regulating MCP-1 Diffusion in Affinity 616 Hydrogels for Enhancing Immuno-isolation. Journal of controlled release : official journal 617 of the Controlled Release Society 142:384-391. DOI: 10.1016/j.jconrel.2009.11.022. 
618 Lotfy M, Kalasz H, Szalai G, Singh J, Adeghate E. 2014. Recent Progress in the Use of

619 Glucagon and Glucagon Receptor Antago-nists in the Treatment of Diabetes Mellitus.

620 The Open Medicinal Chemistry Journal 8:28-35. DOI: 10.2174/1874104501408010028.

621 Margariti A, Winkler B, Karamariti E, Zampetaki A, Tsai T, Baban D, Ragoussis J, Huang Y, Han

622 J-DJ, Zeng L, Hu Y, Xu Q. 2012. Direct reprogramming of fibroblasts into endothelial

623 cells capable of angiogenesis and reendothelialization in tissue-engineered vessels.

624 Proceedings of the National Academy of Sciences of the United States of America

625 109:13793-13798. DOI: 10.1073/pnas.1205526109.

626 Matsumoto S, Shimoda M. 2020. Current situation of clinical islet transplantation from allogeneic 627 toward xenogeneic. Journal of Diabetes. DOI: 10.1111/1753-0407.13041.

628 Maza I, Caspi I, Zviran A, Chomsky E, Rais Y, Viukov S, Geula S, Buenrostro JD, Weinberger

629 L, Krupalnik V, Hanna S, Zerbib M, Dutton JR, Greenleaf WJ, Massarwa R, Novershtern

630 N, Hanna JH. 2015. Transient acquisition of pluripotency during somatic cell

631 transdifferentiation with iPSC reprogramming factors. Nature Biotechnology 33:769-774.

632 DOI: $10.1038 / n b t .3270$.

633 Menge BA, Schrader H, Breuer TGK, Dabrowski Y, Uhl W, Schmidt WE, Meier JJ. 2009.

634 Metabolic consequences of a $50 \%$ partial pancreatectomy in humans. Diabetologia

635 52:306-317. DOI: 10.1007/s00125-008-1219-1.

636 Minami K, Okuno M, Miyawaki K, Okumachi A, Ishizaki K, Oyama K, Kawaguchi M, Ishizuka N, 637 Iwanaga T, Seino S. 2005. Lineage tracing and characterization of insulin-secreting cells 638 generated from adult pancreatic acinar cells. Proceedings of the National Academy of 639 Sciences of the United States of America 102:15116-15121. DOI:

$640 \quad 10.1073 /$ pnas.0507567102.

641 Mitutsova V, Yeo WWY, Davaze R, Franckhauser C, Hani E-H, Abdullah S, Mollard P, 642 Schaeffer M, Fernandez A, Lamb NJC. 2017. Adult muscle-derived stem cells engraft 
643

644

645

646

647

648

649

650

651

652

653

654

655

656

657

658

659

660

661

662

663

664

665

666

667

668

and differentiate into insulin-expressing cells in pancreatic islets of diabetic mice. Stem Cell Research \& Therapy 8. DOI: 10.1186/s13287-017-0539-9.

Nadithe V, Mishra D, Bae YH. 2012. Poly(ethylene glycol) cross-linked hemoglobin with antioxidant enzymes protects pancreatic islets from hypoxic and free radical stress and extends islet functionality. Biotechnology and Bioengineering 109:2392-2401. DOI: 10.1002/bit.24501.

Nakayama M, Beilke JN, Jasinski JM, Kobayashi M, Miao D, Li M, Coulombe MG, Liu E, Elliott JF, Gill RG, Eisenbarth GS. 2007. Priming and effector dependence on insulin B:9-23 peptide in NOD islet autoimmunity. The Journal of Clinical Investigation 117:1835-1843. DOI: $10.1172 / \mathrm{JCl} 31368$.

Pan FC, Bankaitis ED, Boyer D, Xu X, Van de Casteele M, Magnuson MA, Heimberg H, Wright CVE. 2013. Spatiotemporal patterns of multipotentiality in Ptf1a-expressing cells during pancreas organogenesis and injury-induced facultative restoration. Development (Cambridge, England) 140:751-764. DOI: 10.1242/dev.090159.

Pandol SJ. 2010. The Exocrine Pancreas. San Rafael (CA): Morgan \& Claypool Life Sciences. Peloso A, Citro A, Zoro T, Cobianchi L, Kahler-Quesada A, Bianchi CM, Andres A, Berishvili E, Piemonti L, Berney T, Toso C, Oldani G. 2018. Regenerative Medicine and Diabetes: Targeting the Extracellular Matrix Beyond the Stem Cell Approach and Encapsulation Technology. Frontiers in Endocrinology 9. DOI: 10.3389/fendo.2018.00445.

Phadnis SM, Joglekar MV, Dalvi MP, Muthyala S, Nair PD, Ghaskadbi SM, Bhonde RR, Hardikar AA. 2011. Human bone marrow-derived mesenchymal cells differentiate and mature into endocrine pancreatic lineage in vivo. Cytotherapy 13:279-293. DOI: 10.3109/14653249.2010.523108.

Posselt AM, Bellin MD, Tavakol M, Szot GL, Frassetto LA, Masharani U, Kerlan RK, Fong L, Vincenti FG, Hering BJ, Bluestone JA, Stock PG. 2010. ISLET TRANSPLANTATION IN TYPE 1 DIABETICS USING AN IMMUNOSUPPRESSIVE PROTOCOL BASED ON THE 
669

670

671

672 Prasad S, Kohm AP, McMahon JS, Luo X, Miller SD. 2012. Pathogenesis of NOD Diabetes is

ANTI-LFA-1 ANTIBODY EFALIZUMAB. American journal of transplantation : official journal of the American Society of Transplantation and the American Society of Transplant Surgeons 10:1870-1880. DOI: 10.1111/j.1600-6143.2010.03073.x.

673

674

675 Epitope Spreading. Journal of autoimmunity 39:347-353. DOI:

Puissant B, Barreau C, Bourin P, Clavel C, Corre J, Bousquet C, Taureau C, Cousin B, Abbal M, Laharrague P, Penicaud L, Casteilla L, Blancher A. 2005. Immunomodulatory effect of human adipose tissue-derived adult stem cells: comparison with bone marrow mesenchymal stem cells. British Journal of Haematology 129:118-129. DOI: 10.1111/j.1365-2141.2005.05409.x.

Rafael E, Gazelius B, Wu GS, Tibell A. 2000. Longitudinal studies on the microcirculation around the TheraCyte immunoisolation device, using the laser Doppler technique. Cell Transplantation 9:107-113. DOI: 10.1177/096368970000900113.

Rui J, Deng S, Arazi A, Perdigoto AL, Liu Z, Herold KC. 2017. $\beta$ Cells that Resist Immunological Attack Develop during Progression of Autoimmune Diabetes in NOD Mice. Cell metabolism 25:727-738. DOI: 10.1016/j.cmet.2017.01.005.

Salvay DM, Rives CB, Zhang X, Chen F, Kaufman DB, Lowe WL, Shea LD. 2008. Extracellular Matrix Protein-Coated Scaffolds Promote the Reversal of Diabetes After Extrahepatic Islet Transplantation. Transplantation 85:1456-1464. DOI: 10.1097/TP.0b013e31816fc0ea.

Serena C, Keiran N, Ceperuelo-Mallafre V, Ejarque M, Fradera R, Roche K, Nuñez-Roa C, Vendrell J, Fernández-Veledo S. 2016. Obesity and Type 2 Diabetes Alters the Immune Properties of Human Adipose Derived Stem Cells. Stem Cells (Dayton, Ohio) 34:25592573. DOI: $10.1002 /$ stem.2429. 
695 Shapiro AMJ, Pokrywczynska M, Ricordi C. 2017. Clinical pancreatic islet transplantation. $696 \quad$ Nature Reviews Endocrinology 13:268-277. DOI: 10.1038/nrendo.2016.178.

697 Sharma A, Rani R. 2017. Do we really need to differentiate mesenchymal stem cells into insulin698 producing cells for attenuation of the autoimmune responses in type 1 diabetes:

699 immunoprophylactic effects of precursors to insulin-producing cells. Stem Cell Research 700 \& Therapy 8:167. DOI: 10.1186/s13287-017-0615-1.

701 Takahashi H, Sakata N, Yoshimatsu G, Hasegawa S, Kodama S. 2019. Regenerative and 702 Transplantation Medicine: Cellular Therapy Using Adipose Tissue-Derived Mesenchymal 703 Stromal Cells for Type 1 Diabetes Mellitus. Journal of Clinical Medicine 8. DOI:

$704 \quad 10.3390 / j c m 8020249$.

705 Talchai C, Xuan S, Lin HV, Sussel L, Accili D. 2012. Pancreatic $\beta$-Cell Dedifferentiation As 706 Mechanism Of Diabetic $\beta$-Cell Failure. Cell 150:1223-1234. DOI:

$707 \quad$ 10.1016/j.cell.2012.07.029.

708 Teta M, Rankin MM, Long SY, Stein GM, Kushner JA. 2007. Growth and regeneration of adult 709 beta cells does not involve specialized progenitors. Developmental Cell 12:817-826.

710 DOI: 10.1016/j.devcel.2007.04.011.

711 Thorel F, Népote V, Avril I, Kohno K, Desgraz R, Chera S, Herrera PL. 2010. Conversion of 712 713 adult pancreatic alpha-cells to beta-cells after extreme beta-cell loss. Nature 464:1149_

714 Trivedi HL, Vanikar AV, Thakker U, Firoze A, Dave SD, Patel CN, Patel JV, Bhargava AB, 715 Shankar V. 2008. Human adipose tissue-derived mesenchymal stem cells combined 716 with hematopoietic stem cell transplantation synthesize insulin. Transplantation 717 Proceedings 40:1135-1139. DOI: 10.1016/j.transproceed.2008.03.113.

718 Vlahos AE, Cober N, Sefton MV. 2017. Modular tissue engineering for the vascularization of 719 subcutaneously transplanted pancreatic islets. Proceedings of the National Academy of 
720

721

722

723

724

725

726

727

728

729

730

731

732

733

734

735

736

737

738

739

740

741

742

743

744 745

Sciences of the United States of America 114:9337-9342. DOI: 10.1073/pnas.1619216114.

Wang M, Song L, Strange C, Dong X, Wang H. 2018. Therapeutic Effects of Adipose Stem Cells from Diabetic Mice for the Treatment of Type 2 Diabetes. Molecular Therapy: The Journal of the American Society of Gene Therapy 26:1921-1930. DOI: 10.1016/j.ymthe.2018.06.013.

Weber LM, Hayda KN, Anseth KS. 2008. Cell-Matrix Interactions Improve $\beta$-Cell Survival and Insulin Secretion in Three-Dimensional Culture. Tissue Engineering. Part A 14:1959_ 1968. DOI: 10.1089/ten.tea.2007.0238.

Williams DM, Nawaz A, Evans M. 2020. Drug Therapy in Obesity: A Review of Current and Emerging Treatments. Diabetes Therapy: Research, Treatment and Education of Diabetes and Related Disorders. DOI: 10.1007/s13300-020-00816-y.

Wilson JT, Cui W, Kozlovskaya V, Kharlampieva E, Pan D, Qu Z, Krishnamurthy VR, Mets J, Kumar V, Wen J, Song Y, Tsukruk VV, Chaikof EL. 2011. Cell Surface Engineering with Polyelectrolyte Multilayer Thin Films. Journal of the American Chemical Society 133:7054-7064. DOI: 10.1021/ja110926s.

Xu X, D’Hoker J, Stangé G, Bonné S, De Leu N, Xiao X, Van de Casteele M, Mellitzer G, Ling Z, Pipeleers D, Bouwens L, Scharfmann R, Gradwohl G, Heimberg H. 2008. Beta cells can be generated from endogenous progenitors in injured adult mouse pancreas. Cell 132:197-207. DOI: 10.1016/j.cell.2007.12.015.

Xu B, Fan D, Zhao Y, Li J, Wang Z, Wang J, Wang X, Guan Z, Niu B. 2020. Three-Dimensional Culture Promotes the Differentiation of Human Dental Pulp Mesenchymal Stem Cells Into Insulin-Producing Cells for Improving the Diabetes Therapy. Frontiers in Pharmacology 10. DOI: 10.3389/fphar.2019.01576.

Zhang M, Lin Q, Qi T, Wang T, Chen C-C, Riggs AD, Zeng D. 2016. Growth factors and medium hyperglycemia induce Sox9+ ductal cell differentiation into $\beta$ cells in mice with 
746

747

748

749

750

751

752

753

754

755

756

757

758

759

760

761

762

763

764

765

766

767

768

769

770

reversal of diabetes. Proceedings of the National Academy of Sciences of the United States of America 113:650-655. DOI: 10.1073/pnas.1524200113.

Zhao Y. 2012. Stem Cell Educator Therapy and Induction of Immune Balance. Current Diabetes Reports 12:517-523. DOI: 10.1007/s11892-012-0308-1.

Zhao Y, Huang Z, Lazzarini P, Wang Y, Di A, Chen M. 2007. A unique human blood-derived cell population displays high potential for producing insulin. Biochemical and Biophysical Research Communications 360:205-211. DOI: 10.1016/j.bbrc.2007.06.035.

Zhao Y, Jiang Z, Zhao T, Ye M, Hu C, Yin Z, Li H, Zhang Y, Diao Y, Li Y, Chen Y, Sun X, Fisk MB, Skidgel R, Holterman M, Prabhakar B, Mazzone T. 2012. Reversal of type 1 diabetes via islet $\beta$ cell regeneration following immune modulation by cord blood-derived multipotent stem cells. BMC Medicine 10:3. DOI: 10.1186/1741-7015-10-3.

Zhao T, Luo D, Sun Y, Niu X, Wang Y, Wang C, Jia W. 2018. Human urine-derived stem cells play a novel role in the treatment of STZ-induced diabetic mice. Journal of Molecular Histology 49:419-428. DOI: 10.1007/s10735-018-9772-5.

Zhou Q, Brown J, Kanarek A, Rajagopal J, Melton DA. 2008. In vivo reprogramming of adult pancreatic exocrine cells to $\beta$-cells. Nature 455:627-632. DOI: 10.1038/nature07314.

Zhou Q, Melton DA. 2018. Pancreas regeneration. Nature 557:351-358. DOI: 10.1038/s41586018-0088-0.

Zhu Y, Liu Q, Zhou Z, Ikeda Y. 2017. PDX1, Neurogenin-3, and MAFA: critical transcription regulators for beta cell development and regeneration. Stem Cell Research \& Therapy 8:240. DOI: 10.1186/s13287-017-0694-Z.

Zhu S, Wang H, Ding S. 2015. Reprogramming fibroblasts toward cardiomyocytes, neural stem cells and hepatocytes by cell activation and signaling-directed lineage conversion. Nature Protocols 10:959-973. DOI: 10.1038/nprot.2015.059.

PeerJ reviewing PDF | (2020:04:48390:2:0:NEW 17 Jul 2020) 


\section{Table $\mathbf{1}$ (on next page)}

The key regulators of beta-cells 


\begin{tabular}{|c|c|c|}
\hline Designation & Function & References \\
\hline \multicolumn{3}{|c|}{ Transcript factors } \\
\hline Pdx1 & $\begin{array}{l}\text { Essential in early and mature stages of pancreatic } \\
\text { cell development. In early-stage regulates the } \\
\text { formation of the pancreas from foregut endoderm. } \\
\text { In the late stage transactivates the insulin gene }\end{array}$ & $\begin{array}{l}\text { (Kaneto et al., } \\
\text { 2007; Zhu et al., } \\
\text { 2017) }\end{array}$ \\
\hline $\mathrm{Hb} 9$ & Regulates development of the dorsal pancreas & $\begin{array}{l}\text { (Arkhipova et al., } \\
\text { 2012) }\end{array}$ \\
\hline Ngn3 & Critical regulator for pancreatic endocrine fates & $\begin{array}{l}\text { (Akinci et al., } \\
\text { 2012, p. 3; Zhu et } \\
\text { al., 2017) }\end{array}$ \\
\hline NeuroD & $\begin{array}{l}\text { Regulates pancreatic endocrine cell differentiation } \\
\text { and insulin gene transcription }\end{array}$ & (Zhu et al., 2017) \\
\hline Mafa & $\begin{array}{l}\text { Regulates glucose-responsive insulin secretion. This } \\
\text { TF is expressed only in beta-cells }\end{array}$ & $\begin{array}{l}\text { (Wang et al., } \\
\text { 2007; Nishimura, } \\
\text { Bonner-Weir \& } \\
\text { Sharma, 2009; } \\
\text { Zhu et al., 2017) }\end{array}$ \\
\hline Pax4 & Regulates of beta-cell specification & $\begin{array}{l}\text { (Napolitano et } \\
\text { al., 2015) }\end{array}$ \\
\hline Pax6 & Incre & $\begin{array}{l}\text { (Arkhipova et al., } \\
\text { 2012) }\end{array}$ \\
\hline Nkx6.1 & $\begin{array}{l}\text { Guides endodermal progenitors toward beta-cell fate, } \\
\text { must be generated before certain endocrine genes } \\
\text { turn on }\end{array}$ & $\begin{array}{l}\text { (Taylor, Liu \& } \\
\text { Sander, 2013) }\end{array}$ \\
\hline $\mathrm{Nkx2.2}$ & $\begin{array}{l}\text { Critical regulator of pancreatic endocrine cell } \\
\text { specification and differentiation }\end{array}$ & $\begin{array}{l}\text { (Doyle \& Sussel, } \\
\text { 2007) }\end{array}$ \\
\hline \multicolumn{3}{|c|}{ Small molecules } \\
\hline GNF-9228 & Selectively stimulates proliferation of beta-cells & $\begin{array}{l}\text { (Pavathuparambil } \\
\text { Abdul Manaph et } \\
\text { al., 2019) }\end{array}$ \\
\hline $\begin{array}{l}\text { 5'-azacytidine } \\
\text { (5-AZA) }\end{array}$ & $\begin{array}{l}\text { DNA methylation inhibitor; increases the } \\
\text { reprogramming process } 10 \text {-fold }\end{array}$ & $\begin{array}{l}\text { (Hohmeier et al., } \\
\text { 2020) }\end{array}$ \\
\hline $\begin{array}{l}\text { Valproic acid } \\
\text { (VPA) }\end{array}$ & Increases the reprogramming process 100 -fold & $\begin{array}{l}\text { (Hohmeier et al., } \\
2020)\end{array}$ \\
\hline $\begin{array}{l}\text { Indolactam V } \\
\text { (ILV) }\end{array}$ & $\begin{array}{l}\text { Induces differentiation of hesc lines toward Pdx1- } \\
\text { positive pancreatic progenitors }\end{array}$ & $\begin{array}{l}\text { (Hohmeier et al., } \\
2020)\end{array}$ \\
\hline BRD7389 & Induces insulin protein expression in alpha-cells & $\begin{array}{c}\text { (Hohmeier et al., } \\
2020)\end{array}$ \\
\hline $\begin{array}{l}\text { latrunculin A } \\
\text { and B }\end{array}$ & $\begin{array}{l}\text { Induce endocrine differentiation by the } \\
\text { reorganization of the cytoskeleton }\end{array}$ & $\begin{array}{l}\text { (Hogrebe et al., } \\
2020)\end{array}$ \\
\hline $\begin{array}{l}\text { GABA(gamma- } \\
\text { aminobutyric } \\
\text { acid) }\end{array}$ & $\begin{array}{l}\text { Induces alpha-to-beta-cell neogenesis; participates in } \\
\text { maintaining the beta-cell mass and in protecting } \\
\text { beta-cells from apoptosis in vitro }\end{array}$ & $\begin{array}{l}\text { (Ben-Othman et } \\
\text { al., 2017) }\end{array}$ \\
\hline
\end{tabular}




\begin{tabular}{|c|l|c|}
\hline $\begin{array}{c}\text { miR-15a, miR- } \\
\begin{array}{c}\text { 15b, miR-16 } \\
\text { and miR-195 }\end{array}\end{array}$ & Decrease the level of NGN3 gene expression & $\begin{array}{c}\text { (Joglekar et al., } \\
\text { 2007; Wong et } \\
\text { al., 2018) }\end{array}$ \\
\hline miR-7 & Inhibition of proliferation in Langerhans islets & $\begin{array}{c}\text { (Wang et al., } \\
\text { 2013; Wong et } \\
\text { al., 2018) }\end{array}$ \\
\hline $\begin{array}{c}\text { polypyrimidine } \\
\text { tract-binding } \\
\text { protein 1 } \\
\text { (PTBP1) }\end{array}$ & Regulates the stability of insulin mRNA & $\begin{array}{c}\text { (Magro \& } \\
\text { Solimena, 2013) }\end{array}$ \\
\hline $\begin{array}{c}\text { human antigen } \\
\text { (HuD) }\end{array}$ & Binds to insulin mRNA and controls its translation & (Lee et al., 2012) \\
\hline $\begin{array}{c}\text { protein- } \\
\text { disulfide } \\
\text { isomerase } \\
\text { (PDI) }\end{array}$ & $\begin{array}{c}\text { Key regulator of glucose-stimulated insulin } \\
\text { biosynthesis }\end{array}$ & $\begin{array}{c}\text { (Kulkarni et al., } \\
\text { 2011) }\end{array}$ \\
\hline
\end{tabular}


Table 2 (on next page)

The limitations of approaches for the generation of beta-cells 


\begin{tabular}{|c|c|c|c|c|c|c|c|}
\hline & $\begin{array}{l}\text { Ex-vivo } \\
\text { generation } \\
\text { of beta-cells }\end{array}$ & $\begin{array}{l}\text { ESCs } \\
\text { differentiati } \\
\text { on in vitro }\end{array}$ & $\begin{array}{l}\text { iPSCs } \\
\text { differentiation } \\
\text { in vitro }\end{array}$ & $\begin{array}{l}\text { Non-beta } \\
\text { pancreatic cells } \\
\text { transdifferentiation } \\
\text { in vivo }\end{array}$ & $\begin{array}{l}\text { Non-beta } \\
\text { pancreatic cells } \\
\text { transdifferentiation } \\
\text { in vitro }\end{array}$ & $\begin{array}{l}\text { Fibroblasts } \\
\text { transdifferentiation } \\
\text { in vitro }\end{array}$ & References \\
\hline Limited sources & Yes & Yes & No & Yes & Yes & No & $\begin{array}{l}\text { (Huang \& } \\
\text { Chang, 2014) }\end{array}$ \\
\hline $\begin{array}{l}\text { Risk of teratoma } \\
\text { development }\end{array}$ & No & Yes & Yes & No & No & No & $\begin{array}{l}\text { (Hentze et al., } \\
\text { 2009) }\end{array}$ \\
\hline Allograft rejection & No & Yes & No & No & No & No & $\begin{array}{l}\text { (Hentze et al., } \\
\text { 2009) }\end{array}$ \\
\hline $\begin{array}{l}\text { Lack of organization into } \\
\text { islets }\end{array}$ & No & Yes & Yes & Yes & Yes & Yes & $\begin{array}{l}\text { (Zhou et al., } \\
\text { 2008) }\end{array}$ \\
\hline $\begin{array}{l}\text { Lack of reproducibility } \\
\text { of the protocols }\end{array}$ & No & No & No & Yes & Yes & Yes & $\begin{array}{l}\text { (Kim, Jeong \& } \\
\text { Choi, 2020) }\end{array}$ \\
\hline $\begin{array}{l}\text { Off-target effects after } \\
\text { manipulation with } \\
\text { genome }\end{array}$ & No & No & Yes/No* & Yes & Yes/No* & Yes/No* & $\begin{array}{l}\text { (Clayton et al., } \\
\text { 2016) }\end{array}$ \\
\hline $\begin{array}{l}\text { The necessity of deep } \\
\text { invasion for cell product } \\
\text { preparation }\end{array}$ & Yes & No & No & No & Yes & No & $\begin{array}{l}\text { (Trivedi et al., } \\
\text { 2008; Matsumoto } \\
\text { \& Shimoda, } \\
\text { 2020) }\end{array}$ \\
\hline $\begin{array}{l}\text { The necessity of deep } \\
\text { invasion for } \\
\text { transplantation of final } \\
\text { cell product }\end{array}$ & Yes & Yes & Yes & No & Yes & Yes & $\begin{array}{l}\text { (Shapiro, } \\
\text { Pokrywczynska } \\
\text { \& Ricordi, 2017; } \\
\text { Matsumoto \& } \\
\text { Shimoda, 2020) }\end{array}$ \\
\hline
\end{tabular}


Figure 1

The existing approaches for beta-cell recovery

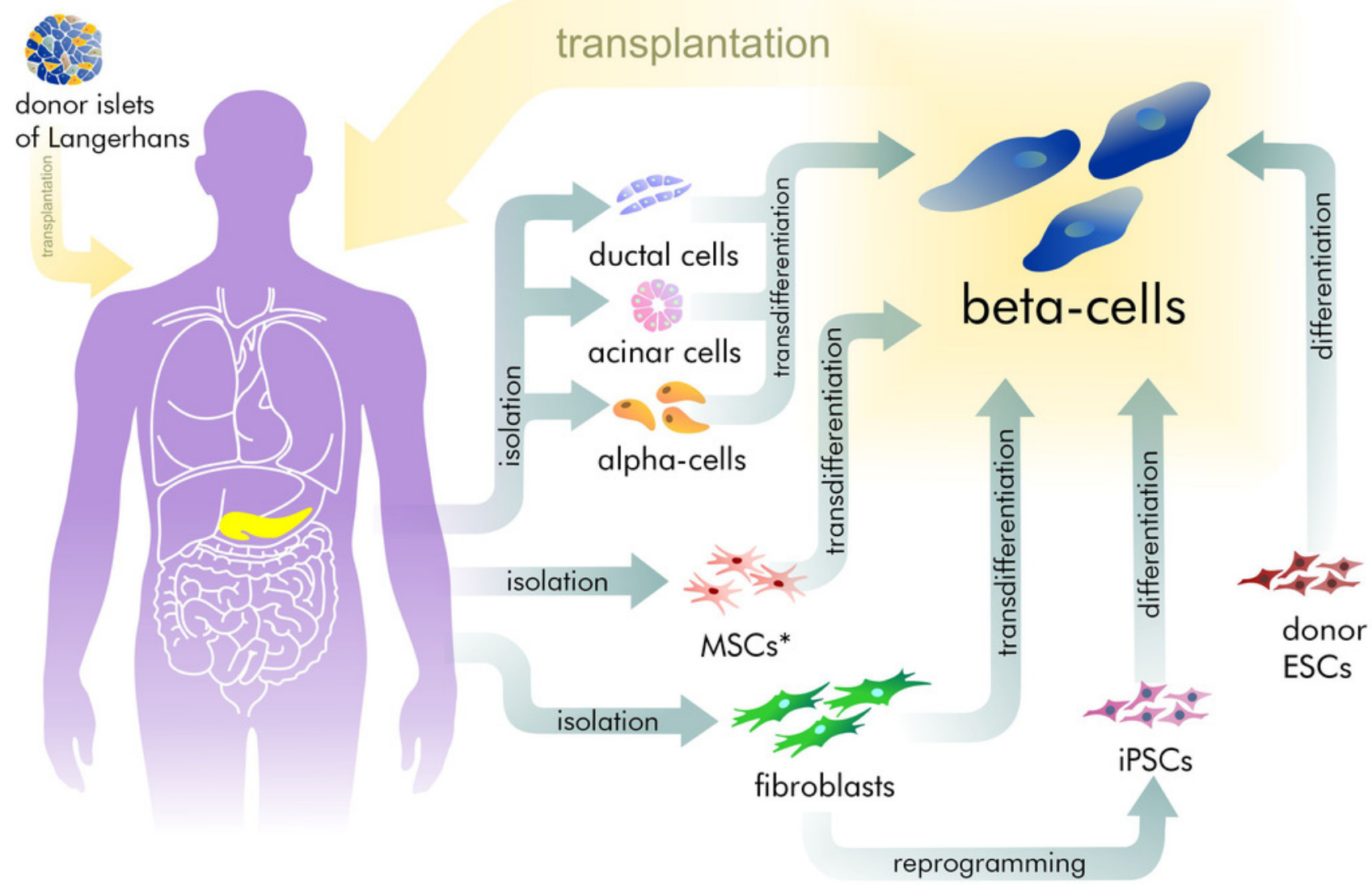

${ }^{*}$ Muscle-derived MSCs, adipose-derived MSCs, bone-marrow-derived MSCs 